\title{
Модель віброкиплячого шару сипких середовищ та її програмна реалізація
}

\author{
С. А. Русанов ${ }^{1}$ К. В. Луняка ${ }^{2}$, Д. В. Коновалов ${ }^{2 凶}$, А. А. Андрєєва \\ ${ }^{1}$ Херсонський Національний технічний університет, Бериславське шосе, 24, м. Херсон, 73008, Україна \\ ${ }^{2}$ Херсонська філія Національного університету кораблебудування ім. адм. Макарова, пр. Ушакова, 44, м. Херсон, \\ 73003, Україна \\ $\triangle$ e-mail: dimitriyko79@gmail.com
}

\begin{abstract}
У статті представлена математична модель процесу віброкипіння, яка з єдиних позицій описує структуру й поведінку віброкиплячого шару в різних умовах, дозволяє спрогнозувати поведінку віброкиплячого шару в цілому для широкого спектру впливаючих чинників: фізичних властивостей сипкого матеріалу $і$ газового середовища, геометрії робочого органу, параметрів вібрації, особливостей взаємодї фаз між собою $і$ з вантажонесучими поверхнями. Одержана модель дозволяє автоматизувати обчислення з використанням мінімального набору вхідних даних. Одержані рівняння, які описують поведінку віброкиплячого шару як суцільного середовища $з$ особливою реологією, в якій за рахунок підведеної зовнішньої вібрації розповсюджуються нелінійні хвилі деформації з періодичними змінами щільного і розпушеного стану. Створена система автоматизованого моделювання поведінки віброкиплячих шарів "Віброслой", яка дозволяє провести моделювання поведінки віброкиплячого шару сипкого матеріалу з урахуванням фізичних параметрів середовища й газової фази, параметрів вібрації, особливостей фільтраиії газу і властивостей робочих органів для ефективного проектування устаткування $з$ віброкиплячим шаром. Проведені тестові моделювання одиничного підкидання шару сипкого матеріалу, визначення швидкостей течії шару на вібруючих поверхнях із зіставленням з експериментальними даними. Показана можливість прогнозування параметрів сталих (стаціонарних течій) віброкиплячого шару на протяжних вібруючих поверхнях.
\end{abstract}

Ключові слова: Віброкипіння, Віброзрідження, Математичне моделювання, Сипкі матеріали, Гідродинаміка, Системи автоматизованого моделювання.

(C) The Author(s) 2018. This article is an open access publication

This work is licensed under the Creative Commons Attribution 4.0 International License (CC BY) http://creativecommons.org/licenses/by/4.0/

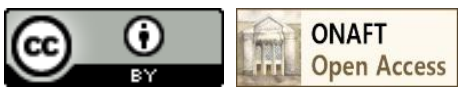

\section{1. Вступ}

Використання вібраційних методів в технологіях різних галузей має поширення не тільки за рахунок відомих інтенсифікуючих властивостей вібрацій, але й у зв'язку з можливістю поєднання двох або декількох технологічних операцій. Наприклад, в харчових технологіях досить просто поєднується транспортування дисперсних або штучних матеріалів з теплообмінними або масообмінними процесами, наприклад, обробка сировини у вібраційній сушарці-млині. Але проектування ефективного обладнання стримується недостатньою вивченістю деяких закономірностей процесу вібраційного спонукання в шарі.

Існує досить багато спроб об'єднання сукупності спостережуваних фактів процесу віброспонукання в рамках однієї теорії. Ті або інші аспекти вдається описати різними моделями, проте достатньо надійної методики прогнозування поведінки віброкиплячого шару до цього часу не створено, і всі існуючі моделі мають вузьку область застосування. Відсутність можливості надійного прогнозування поведінки віброкиплячих шарів стримує процес впровадження обладнання для обробки сипких матеріалів у віброкиплячому шарі у виробництво.

Таким чином, формування адекватної математичної моделі, що відповідає експериментальним даним і до- зволяє автоматизувати обчислення в широкому спектрі вхідних даних з урахуванням виробничих та проектних потреб, обумовлює необхідність проведення досліджень в цьому напрямку.

\section{2. Аналіз літературних даних та постановка проблеми}

Існуючі методики розрахунків не надають для значної кількості задач достатньої точності, мають обмежений діапазон застосування в досить вузькій смузі кутів вібрації, інтенсивності вібраційного спонукання та багатьох інших факторів [1]. Окремо треба виділити щільні шари дисперсних матеріалів, де на перший план виходять внутрішні напруги, зчеплення частинок, фільтрація газу, вплив граничних та початкових умов - в таких шарах поведінка частинок буде суттєво залежна від параметрів вібрації: при низькій вібраційній інтенсивності шар знаходиться в стані віброзрідження, при подальшому збільшенні вібраційних впливів шар переходить у стан віброкипіння [1-4]. Гідродинаміка шарів у вказаних станах різко відрізняється.

У загальному випадку задача гідродинаміки віброзріджених та віброкиплячих шарів відноситься до задач віброреології [5-7]. Відомо [5], що кількісний опис залежності реологічних параметрів оброблюваного вібромашинами середовища від параметрів вібраційно- 
го фону становить так звану першу задачу віброреології. Розв'язок цієї задачі повною мірою дотепер не знайдений, що пов'язано не тільки зі складністю зазначеного завдання, але, зокрема, і з нерозв'язаністю підзадач, які $\epsilon$ етапами розв'язку, наприклад, задачі з опису зв'язків між реологічними параметрами середовища й амплітудно-частотною характеристикою вібромашини, опис загального руху середовища, що піддане вібраційному фону. Окремою проблемою висувається задача математичного опису хоча б ламінарних стійких стаціонарних плинів дисперсних структур. Це формує другу задачу віброреології. Вибір оптимального режиму роботи вібромашини становить третю задачу [5].

Значно відрізняються також процеси в залежності від відносної (до характерного розміру частинок) висоти шару. Для достатньо високих шарів спостерігаються процеси самофільтрації газової фази [1], формування циркуляційних потоків на кшталт комірок Бенара [8] тощо. Моделі, що описують поведінку віброкиплячих шарів зазвичай $є$ досить складними нелінійними системами диференціальних рівнянь в часткових похідних $[8,9,10]$; в інших випадках вони описують шар сипкого матеріалу або як феноменологічну нестаціонарну систему, або як випадок псевдозрідженого шару за напрацьованими на сьогодні методами його моделювання на кшталт [11, 12]. Усі подібні моделі потребують або великої кількості феноменологічних констант, або працюють в достатньо вузькому спектрі вхідних даних та не можуть надати достатньої кількості вихідних параметрів, які потрібні для повноцінного проектування відповідного обладнання (наприклад, витратних характеристик, ударних навантажень тощо). Окрім того, чисельна реалізація алгоритмів за такими моделями, або за моделями, що закладені в CFD-системи загального користування, або за моделями, що реалізують метод дискретного елементу DEM, часто $є$ надзвичайно ресурсоємною та дуже негнучкою [12-15].

Таким чином, створення простої і достатньо точної математичної моделі віброкиплячого шару і на ii базі системи автоматизованого проектування гідродинаміки віброкиплячих шарів з метою прогнозування поведінки сипкого середовища залежно від властивостей твердого матеріалу та газу, геометрії робочого органу обладнання, параметрів вібровпливів тощо є актуальною задачею проектування вібромашин.

Мета дослідження - створення достатньо точної математичної моделі, яка описує структуру і поведінку віброкиплячого шару в різних умовах в широкому спектрі вхідних даних з урахуванням виробничих та проектних потреб, моделювання процесу зі створенням відповідного програмного забезпечення, проведення експериментальних тарирувальних досліджень гідродинаміки віброкиплячих шарів зі співставленням з результатами чисельних розрахунків.

\section{3. Результати дослідження}

Була розвинута математична модель, у відповідності 3 якою віброшар дисперсного матеріалу представлений як суцільне середовище з особливою реологією (обумовленою наявністю фільтруючого середовища, у більшості випадків - газу), в якому за рахунок підведеної зовнішньої вібрації поширюються нелінійні хвилі дефор- мації [16-18]. Вказана модель акумулює з одного боку методи різномодульної теорії пружності $[19,20], 3$ іншого - методи реології гранульованих двофазних середовищ [12].

Класична система рівнянь руху та нерозривності для двофазового середовища [12] була спрощена з урахуванням значних перепадів тиску газової фази над та під шаром [1]. При цьому отримана система рівнянь, що описує гідродинаміку процесу віброкипіння шарів дисперсних середовищ:

$$
\begin{aligned}
& \varepsilon_{s}=\frac{\varepsilon_{s o}(\mathbf{r})}{1+\operatorname{divu}}, \\
& \frac{\partial \rho_{g}}{\partial t}=\frac{\operatorname{div}\left[\rho_{\mathrm{g}}\left(1-\varepsilon_{s}\right) k \cdot \operatorname{grad} p\right]}{\left(1-\varepsilon_{s}\right) \mu}-\frac{\rho_{g}}{1-\varepsilon_{s}} \frac{\partial \operatorname{div} \mathbf{u}}{\partial \mathrm{t}}-\frac{\partial \mathbf{u}}{\partial t} \cdot \operatorname{grad} \rho_{g}, \\
& \rho_{s} \varepsilon_{s} \frac{\partial^{2} \mathbf{u}}{\partial t^{2}}=-\varepsilon_{s} \operatorname{grad} p+\operatorname{Div} \boldsymbol{\tau}_{s}+\rho_{s} \varepsilon_{s} \mathbf{g}+\mathbf{R},
\end{aligned}
$$

де $\varepsilon_{s o}(\mathbf{r})$ - початковий розподіл об'ємної концентрації твердої фази по області $\Omega$, що зайнята віброкиплячим шаром; u - вектор переміщення центра тяжіння системи частинок, що знаходяться всередині елементарного фізичного об'єму dV з радіус-вектором r, виділеним в області $\Omega ; \mathrm{k}$ - проникність шару; $\mu$ - динамічна в'язкість газу; $\tau \mathrm{s}$ - тензор напруг, які виникають при взаємодії частинок.

Таким чином, у рамках вказаної моделі віброкиплячий шар (двофазне середовище) за рахунок його характерних особливостей був представлений як суцільне однофазове середовище з особливою реологією, в якому за рахунок підведеної зовнішньої вібрації поширюються нелінійні хвилі деформації з періодичними змінами щільного та розпушеного стану.

Наступним етапом роботи було моделювання течії віброкиплячого шару в каналі. При цьому малося на увазі, що в багатьох виробничих випадках рух дисперсного матеріалу в апаратах з віброкиплячим шаром відповідає плоскій задачі течії віброшару між двома поверхнями, яку можна отримати осередненням просторових рівнянь за шириною каналу - це істотно спрощує завдання та дозволяє створити ефективні чисельні алгоритми та автоматизувати обчислення. Зведення просторової моделі, елементи якої вказані вище, до плоскої з адекватним врахуванням зовнішніх впливових чинників 3 наступною алгоритмізацією в рамках системи автоматизованого моделювання, що відповідає сучасним вимогам, проведено таким чином.

Задача моделює двовимірний процес в апаратах 3 протяжними вібруючими поверхнями та відповідає руху віброкиплячого шару в прямокутному лотку, розташованому під кутом $\alpha$ до горизонту. Лоток здійснює рухи, що описуються векторною функцією зміщень вантажонесучої поверхні у часі, при цьому на вказану залежність не накладається жодних обмежень. Верхня поверхня (кришка, якщо вона $є$ ) також може здійснювати рухи (незалежні від рухів нижньої поверхні), що описуються векторною функцією. Матеріал що знаходиться в лотку, має висоту шару Н та займає всю ширину лотка h. Довжина лотка вважається набагато більшою за інші розміри.

У зв'язку зі специфікою задачі до зусиль $\mathrm{R}$ з рівняння руху системи (1) необхідно внести додаткові зусилля від взаємодії бічних стінок та шару. Таким чином, вра- 
ховуються сили взаємодії частинок і газу $\mathrm{R}_{\mathrm{gs}}$, зусилля від тертя об бічну поверхню $\mathrm{R}_{\mathrm{ts}}$, адгезійних зв'язків $\mathrm{R}_{\mathrm{as}}$ та зусилля від взаємодії частинок і бічної стінки в розпушеному стані $\mathrm{R}_{\beta}$.

Стосовно до математичної моделі для задачі, що розглядається, параметри віброкипіння усереднювали по ширині лотка й вважали, що для досить протяжного шару параметри процесу віброкипіння не змінюються вздовж координати х, тобто

$$
\frac{\partial \boldsymbol{\Pi}}{\partial x}=0
$$

де П - будь-який параметр задачі.

При переміщенні відносно осі у (перпендикулярної до несучої поверхні) шар періодично повертається у початковий стан (стикається 3 платформою), тому процес віброкипіння можна представити як пружне деформування щодо даної осі, при цьому пружні властивості віброшару різні для стадії польоту (розпушений стан), та для щільного стану. У той самий час переміщення відносно осі х (співвісної з несучою поверхнею) містять у собі переміщення шару як цілого, які можуть бути представлені як залишкові деформації. Відповідно до цього система (1), що містить рівняння руху відносно осей у і х, рівняння фільтрації газу, доповнена реологічними рівняннями деформування шару для розглянутої задачі, з врахуванням того, що $\varepsilon_{s}+\varepsilon_{g}=1$, умови (2), та рівняння фільтрації як нелінійного закону Дарсі, набуває вигляду:

$\varepsilon_{s} \rho_{s} \frac{\partial^{2} u_{y}}{\partial t^{2}}=-\varepsilon_{s} \frac{\partial p}{\partial y}+\frac{\partial \sigma}{\partial y}-\varepsilon_{s} \rho_{s} g_{y}-R_{y}$,

$\varepsilon_{s} \rho_{s} \frac{\partial^{2} u_{x}}{\partial t^{2}}=\frac{\partial \tau}{\partial y}-\varepsilon_{s} \rho_{s} g_{x}-R_{x}$,

$\frac{\partial \rho_{g}}{\partial t}=\frac{\frac{\partial}{\partial y}\left[\rho_{\mathrm{g}}\left(1-\varepsilon_{s}\right) k \frac{\partial p}{\partial y}\right]}{\left(1-\varepsilon_{s}\right) \mu}-\frac{\rho_{g}}{1-\varepsilon_{s}} \frac{\partial^{2} u_{y}}{\partial t \partial y}-\frac{\partial u_{y}}{\partial t} \cdot \frac{\partial \rho_{g}}{\partial y}$,

де $\tau$ - дотичні напруги в шарі матеріалу; $\sigma$ - нормальні напруги в шарі.
Отримана система диференційних рівнянь разом 3 умовами однозначності чисельно вирішується за допомогою методу скінченних різниць. Запис скінченнорізницевих рівнянь здійснюється за допомогою явної і неявної схем. Нелінійні системи вирішуються стандартним методом Ньютона. Подібна схема забезпечує хорошу стійкість різницевого рішення.

За вказаною моделлю була розроблена система автоматизованого моделювання гідродинаміки віброкиплячих шарів "Віброслой" [21]. Вхідні параметри в середовищі програмного продукту "Віброслой" можуть задаватися в загальному вигляді як аналітичні залежності від основних параметрів процесу (часу та координат, діаметру частинок та фактору форми, в'язкості газового середовища, об'ємної маси фаз та швидкостей і градієнтів швидкостей твердої та газової фази, порізності, переміщень та градієнтів переміщень частинок, тиску та градієнту тиску тощо). Система має багатовіконний інтерфейс користувача (GUI) та дозволяє проводити серії моделювань поведінки шарів сипких середовищ для широкого спектру вхідних даних.

За вказаною моделлю проводилися чисельні розрахунки багатьох задач віброкипіння. Порівняння задачі одиничного підкидання шару дисперсного матеріалу 3 класичними експериментами W. Kroll [22] (скляні частинки) мають задовільний збіг та показані на рис. 1.

Тестові задачі показали також достатній збіг з відомими даними щодо вібротранспортування для еталонного матеріалу (пісок висотою шару $\mathrm{H}=50$ мм при горизонтальному розташуванні вібромашини та куті вібрації $\beta=20^{\circ}$, що рухається на достатньо широкому лотку [2]) - задовільні для технічних потреб результати отримані для усього діапазону параметру перевантаження [1-3] (що характеризує інтенсивність вібровпливів), та який для випадку, що розглядається, має вигляд $\Gamma=A \omega^{2} \sin (\beta) / g$, де А - амплітуда вібрації, $\omega$ - кругова частота коливань, $\beta$ - кут вібрації. Найліпша відповідність до натурних даних отримана в області віброкипіння середньої інтенсивності.

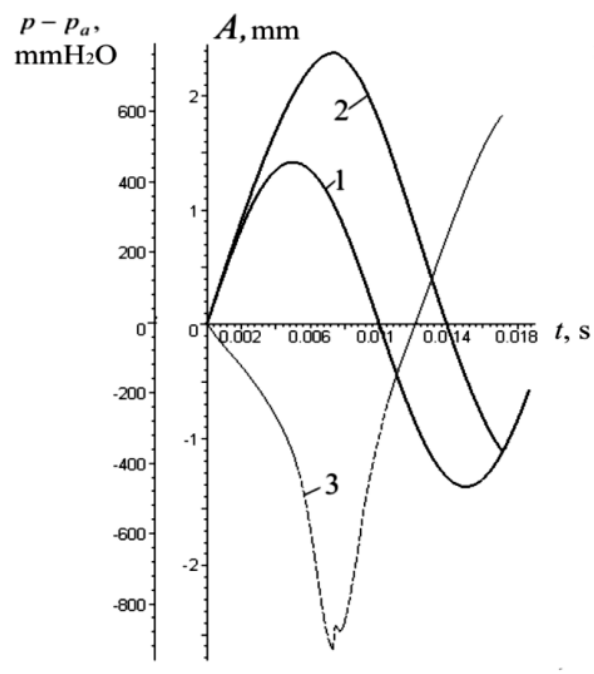

a)

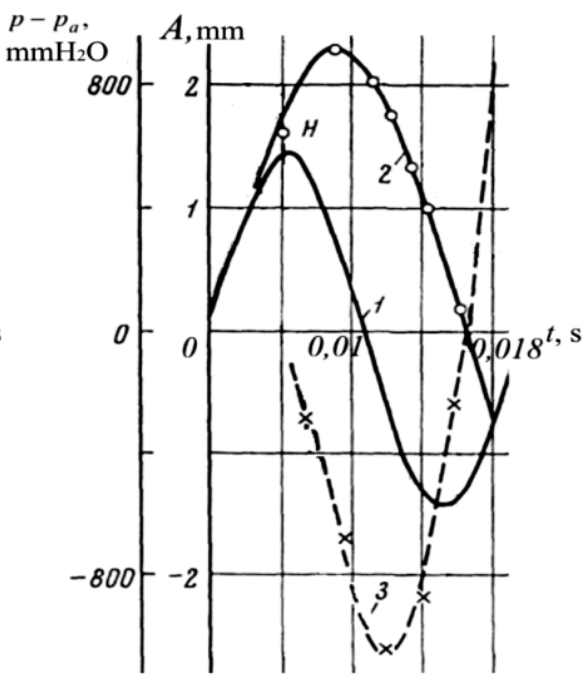

б)

Рисунок 1 - Співставлення результатів моделювання руху сферичних скляних частинок (залежність амплітуди підкидання А та тиску під шаром матеріалу р від часу t) на вертикально вібруючій поверхні (а) з експериментальними даними, щяо наведені в [22] (б); 1 - рух вібруючої поверхні, 2 - рух частинок матеріалу, 3 - графік тиску. 
Для додаткових тестових випробувань в умовах стисненої течії була проведена серія натурних експериментів 3 аналізу гідродинаміки віброкиплячого шару на експериментальному вібростенді за допомогою відеозйомки 3 наступною покадровою обробкою [23]. На рис. 2 представлені результати співставлення швидкості вібротранспортування для прямокутних лотків 3 $\mathrm{H} / \mathrm{h} \geq 1$ (стиснений рух), отримані експериментально та розраховані за розвинутою моделлю.

Вирішувалась задача взаємодії віброшару з несучими поверхнями [24], були отримані реологічні характеристики ламінарного стійкого плину дисперсного шару по вібруючій поверхні (друга задача віброреології) та було показано, що віброкиплячий шар 3 позицій віброреології відноситься до псевдопластичних рідин [25].

Однією з найважливіших особливостей вказаної моделі $є$ можливість розрахунків стаціонарних течій шарів віброшарів. На рис. 3 як приклад вказано вихід на стаціонарний режим руху дисперсного матеріалу на вібруючому нахиленому лотку без проковзування (а) та за наявності відносного проковзування шарів (б).

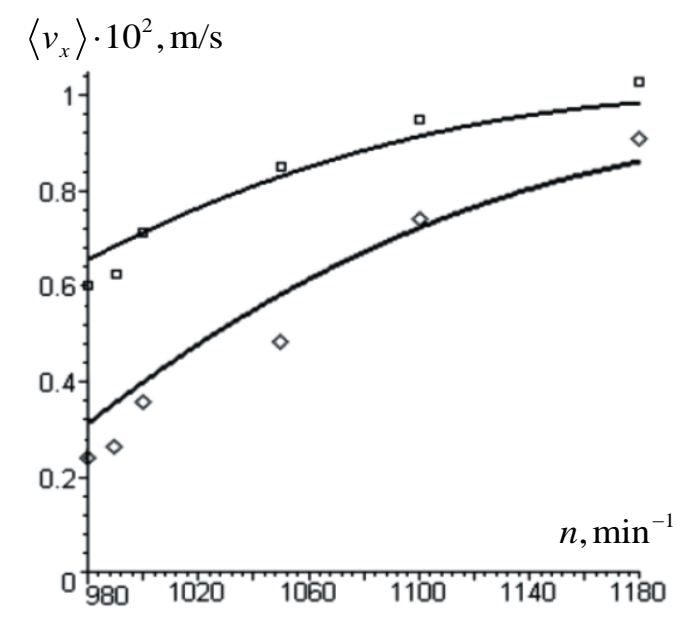

Рисунок 2 - Залежність швидкості вібротранспортування $\left\langle v_{x}\right\rangle$ піску в лотку прямокутного перерізу від частоти вібрації п при куті нахилу $\alpha=3^{\circ}$ (口) та $\alpha=6^{\circ}$

$(\diamond)$, суиільна крива - за програмою "Виброслой".

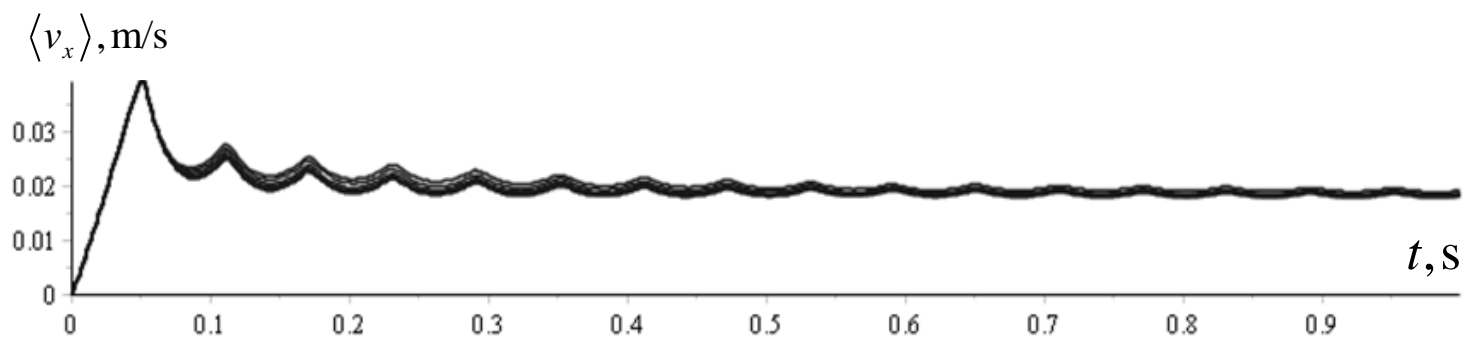

a)

$\left\langle v_{x}\right\rangle, \mathrm{m} / \mathrm{s}$

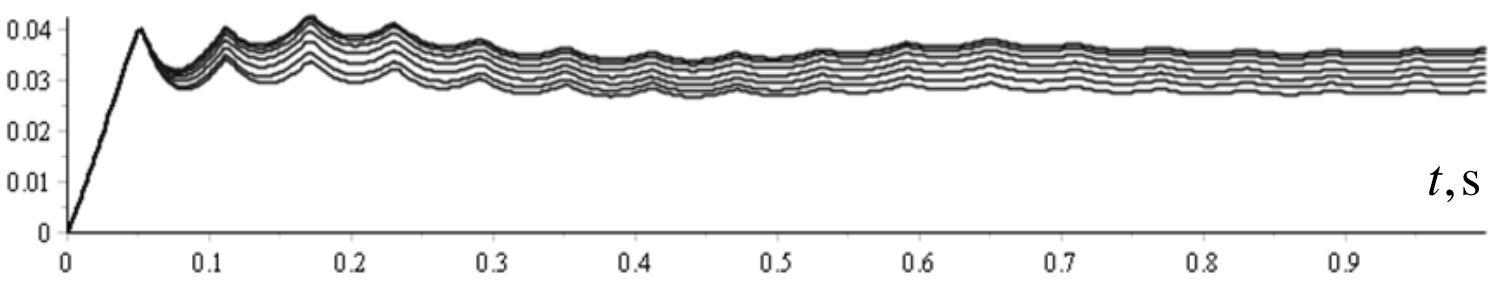

б)

Рисунок 3 - Спостереження виходу на стаціонарний режим течї за осередненою швидкістю дисперсного матеріалу у часі $t$ на вібруючій нахиленій поверхні без проковзування (а) та з проковзуванням шарів (б) за даними "Виброслой"

Запропонована модель віброкиплячого шару та система "Виброслой" дозволяє проводити розрахунки витратних характеристик вібраційного обладнання, визначення ударних навантажень на вібруючі несучі поверхні, резонансних характеристик обладнання, визначення профілів швидкостей по висоті шару (для наступного моделювання теплообміну та масообмінних процесів в шарі матеріалу) тощо. Окрім того, система дозволяє спрогнозувати протікання технологічного процесу для нестандартних проблем (за умови наявності даних щодо проникності шару) на кшталт віброобробки сипких матеріалів в рідинному середовищі, динаміки потоку волокнистих матеріалів, матеріалів 3 особливою реологією, зі складними формами руху вібруючих поверхонь. Модель позбавлена таких суттєвих недоліків, що характерні для двофазних моделей, реалізованих в CFD-системах загального користування, як проблема розмиття границі розділу фаз (чисельна дифузія розрахункових методів), необхідність адаптивної сітки на границі, практична неможливість прогнозування витратних характеристик обладнання тощо.

3 іншого боку необхідно зазначити обмеженість наявної алгоритмічної реалізації в ракурсі можливості моделювання задач обтікання складних занурених елементів, течії в каналах, що звужуються, тощо. Для вказаних цілей необхідний перехід від плоскої задачі до 
тривимірної та залучення додаткових феноменологічних моделей для зовнішньої або змішаної гідродинамічної задачі.

\section{Висновки}

Запропонована модель віброкиплячого шару сипких середовищ та на іiї основі створена система автоматизованого моделювання гідродинаміки віброкиплячих шарів "Виброслой". Проведені тестові дослідження, які показали достатній збіг з відомими даними щодо вібротранспортування для еталонного матеріалу. Модель надає можливість визначення ударних навантажень на вібруючі несучі поверхні, резонансних характеристик обладнання, визначення профілів швидкостей по висоті шару (для наступного моделювання теплообміну та масообмінних процесів в шарі матеріалу), що може бути безпосередньо використане для повноцінного проектування відповідного енергозберігаючого обладнання.

\section{Література}

1. Членов В.А. Виброкипящий слой [Текст] / В.А. Членов, Н.В. Михайлов. - М.: Наука, 1972. - 344 с.

2. Вибрации в технике [Текст]. Справочник: В 6 т. / Г.Г. Азбель, И.И. Блехман, И.И. Быховский и др.; под ред. Э.Э. Лавендела. - М.: Машиностроение, 1981. - Т.4. -509 c.

3. Каталымов А.В. Дозирование сыпучих и вязких материалов [Текст] / А.В. Каталымов, В.А. Любартович. - Л.: Химия, 1990. -240 с.

4. Гончаревич И.Ф., Фролов К.В. Теория вибрационной техники и технологии [Текст] / И.Ф. Гончаревич, К.В. Фролов - М.: Наука, 1981. - 320 с.

5. Овчинников П.Ф. Виброреология [Текст] / П.Ф. Овчинников. - Киев: Наукова думка, 1983. - 272 с.

6. Блехман И.И. Вибрационная механика [Текст] / И.И. Блехман. - М.: Физматлит, 1994. - 400 с.

7. Blekhman, I. Vibrational Mechanics. Nonlinear Dynamic Effects, General Approach, Applications [Text]. / I. Blekhman. - World Scientific, Singapore, 2000. - 509 p.

8. Федоренко И.Я. Анализ поведения сыпучей среды при вибрации на основе теории аттрактора Лоренца [Текст] / И.Я. Федоренко // Известия Сибирского отделения АН СССР. Серия техн. наук, 1990. - Вып. 3. C. 112-115.

9. Раскин Х.И. Применение методов физической кинетики к задачам вибрационного воздействия на сыпучие среды [Текст] / Х.И. Раскин //ДАН СССР. - 1975. т. 220, №1. - С.54-57.

10. Martin T.W. Hydrodynamic model for a vibrofluidized granular bed [Text] / T.W. Martin, J.M. Huntley, R.D. Wildman // J. Fluid Mech. - 2005. - V. 535. - P. 325-345.

11. Gidaspow, D. Multiphase flow and fluidization: Continuum and kinetic theory descriptions [Text]. - Boston: Academic Press Inc. - 1994. - 211 p.

12. Huilin, L. Numerical simulations of hydrodynamic behavior in spouted beds [Text]/ L. Huilin, S. Yongli, L. Yang, H. Yurong and J. Bouillard // Trans. Inst. Chem. Eng. - 2001. - 79. - P. 593-599.

13. Gidaspow D. Hydrodynamics of circulating fluidizes beds, kinetic theory approach [Text] / D. Gidaspow, R. Bezburuah, J. Ding. // In fluidization VII, Proceeding of the 7 th engineering foundation conference on fluidization. 1992. - P. 75-82.

14. Williams, J.R. The Theoretical Basis of the Discrete Element Method [Text] / J.R. Williams, G. Hocking, G.G.W. Mustoe // NUMETA 1985, Numerical Methods of Engineering, Theory and Applications, Rotterdam. - 1985. - P. 7-11.

15. Kawaguchi, T. Numerical simulation of twodimensional fluidized beds using the discrete element method (comparison between the two- and threedimensional models) [Text] / T. Kawaguchi, T. Tanaka, Y. Tsuji // Powder Technology. - 1998. - 96 (2). - P. 129-138. 16. Русанов С.А. Моделювання гідродинаміки віброкиплячих шарів [Текст] / С.А. Русанов, К.В. Луняка, В.Д. Михайлик // Вісник Тернопільського державного університету. - 2006. - № 3. - С. 188-195.

17. Русанов С.А. Дослідження процесу віброкипіння дисперсних середовищ [Текст] / С.А. Русанов, К.В. Луняка, П.В. Смагін // Вісник Хмельницького національного університету. - 2007. - №1. - С.132-141.

18. Русанов С.А. Некоторые теоретические аспекты процесса виброкипения [Текст] / С.А. Русанов, К.В. Луняка, В.А. Ардашев // Восточно-европейский журнал передовых технологий. - 2007. - №6/5 (30). - С.23-25.

19. Амбарцумян С. А. Разномодульная теория упругости [Текст] / Амбарцумян С. А. - М.: Наука, 1982. $317 \mathrm{c}$.

20. Садовская О.В. Математическое моделирование в задачах механики сыпучих сред. Монография. [Текст] / О.В. Садовская, В.М. Садовский. - М.: Физматлит, 2008. -368 c.

21. Система автоматизованого моделювання гідродинаміки віброкиплячих шарів "Виброслой 1.0" [Текст]. Свідоцтво про реєстрацію авторського права на твір №25051. / С.А. Русанов: Заявл. 14.04.2008; Опубл. 24.07.2008.

22. Kroll W. Fliesserscheinungen auf Haufwerken in schwingenden Gefassen [Text] / W. Kroll. // Chemic Ingenieur Technik. - 1955. - №1. - P. 142-148.

23. Русанов С.А. Моделювання гідродинаміки віброкиплячих шарів з розробкою утилізатора тепла сипких матеріалів [Текст]: дис. ... канд. техн. наук / С.А. Русанов. - Херсон, 2008. - 189 с.

24. Русанов С.А. Взаємодія віброкиплячого шару 3 несучими поверхнями [Текст] / С.А. Русанов, К.В. Луняка, О.І. Клюєв, Г.М.Глухов // Восточно-европейский журнал передовых технологий. - 2009. - №5/5 (41). C. 9-14.

25. Rusanov S.A. Vibrorheological model of the vibrofluidized bed of dry substances [Text] / S.A. Rusanov, K.V. Lunyaka, G.V. Nikitenko // JOUR

Отримана в редакції 23.10.2018, прийнята до друку 04.12.2018 


\title{
Model of the vibrofluidized bed of dry substances and its program realization
}

\author{
Serhii Rusanov ${ }^{1}$, Klara Lunyaka ${ }^{2}$, Dmytro Konovalov ${ }^{2}$, Nataliia Andrieieva ${ }^{2}$ \\ ${ }^{1}$ Kherson National Technical University, Berislav highway, 24, Kherson, Ukraine, 73008 \\ ${ }^{2}$ Admiral Makarov National University of Shipbuilding (Kherson branch), Ushakov Avenue, 44, Kherson, Ukraine
}

\begin{abstract}
The mathematical model of process of vibratory boiling layers, which from single positions describes a structure and conduct of vibratory boiling layer in different terms, is represented in the article, allows forecast the conduct of vibratory boiling layer on the whole for the wide spectrum of influences: physical properties of friable material and gas environment, geometry of working organ, parameters of vibration, features of co-operation of phases between itself and with loud bearing surfaces. The got model allows to automatize the calculation with the use of minimum entrance data set. Equalizations, which describe the conduct of vibratory boiling layer as continuous environment with special reology in which the nonlinear waves of deformation with the periodic changes of the dense and made light state spread due to the brought external vibration, are got. The system of the automated design of conduct of the vibratory boiling layers "Vibrosloy", which allows to conduct the design of conduct of vibratory boiling layer of friable material taking into account the physical parameters of environment and gas phase, parameters of vibration, features of filtration of gas and properties of working organs for the effective planning of equipment with a vibratory boiling layer, is created.

The test designs of the single throwing up of layer of friable material are conducted, determination of speeds of flow on vibrating surfaces with comparison with experimental information. Possibility of prognostication of parameters of set (stationary flows) is shown vibratory boiling layer on extensive vibrating surfaces.
\end{abstract}

Keywords: Vibratory boiling layers, Vibration, Mathematical design, Friable materials, Hydrodynamics, Systems of the automated design

\section{References}

1. Chlenov V.A. Mykhailov N.V. (1972). Vybrokypiashchyi sloi. M.: Nauka, 344.

2. Azbel H.H., Blekhman Y.Y. Bykhovskyi Y.Y. y dr.; pod red. E.E. Lavendela (1981). Vybratsyy v tekhnyke. Spravochnyk: V 6 t. M.: Mashynostroenye, 4, 509.

3. Katalymov A.V. Liubartovych V.A. (1990). Dozyrovanye sypuchykh y viazkykh materyalov. L.: Khymyia, 240.

4. Honcharevych Y.F., Frolov K.V. (1981). Teoryia vybratsyonnoi tekhnyky y tekhnolohyy M.: Nauka, 320.

5. Ovchynnykov P.F. (1983). Vybroreolohyia. Kyev: Naukova dumka, 272.

6. Blekhman I.I. (1994). Vybratsyonnaia mekhanyka. M.: Fyzmatlyt, 400.

7. Blekhman, I. (2000). Vibrational Mechanics. Nonlinear Dynamic Effects, General Approach, Applications World Scientific, Singapore, 509.

8. Fedorenko I.Ia. (1990). Analyz povedeniia sypuchei sredy pri vibratsii na osnove teorii attraktora Lorentsa.Yzvestyia Sybyrskoho otdelenyia AN SSSR. Seriia tekhn. Nauk, 3, 112-115.

9. Raskyn Kh.I. (1975). Primenenye metodov fizicheskoi kinetiki $\mathrm{k}$ zadacham vibratsionnoho vozdeistviia na sypuchie sredi. DAN SSSR. 220, 1, 54-57.

10. Martin T.W., Huntley J.M., Wildman R.D. (2005). Hydrodynamic model for a vibrofluidized granular bed, $535,325,345$.

11. Gidaspow, D. (1994). Multiphase flow and fluidization: Continuum and kinetic theory descriptions. Boston: Academic Press Inc. 211.
12. Huilin, L. Yongli, L. Yang, H. Yurong and Bouillard J. (2001). Numerical simulations of hydrodynamic behavior in spouted beds. Trans. Inst. Chem. Eng. 79, 593-599.

https://doi.org/10.1205/02638760152424370

13. Gidaspow D., Bezburuah R., Ding J. (1992). Hydrodynamics of circulating fluidizes beds, kinetic theory approach. In fluidization VII, Proceeding of the 7 th engineering foundation conference on fluidization, 75-82.

14. Williams, J.R. Hocking G., Mustoe G.G.W. (1985). The Theoretical Basis of the Discrete Element Method. NUMETA 1985, Numerical Methods of Engineering, Theory and Applications, Rotterdam, 7-11.

15. Kawaguchi T., Tanaka T., Tsuji Y. (1998). Numerical simulation of two-dimensional fluidized beds using the discrete element method (comparison between the two- and three-dimensional models), 96, 2, 129-138.

https://doi.org/10.1016/S0032-5910(97)03366-4

16. Rusanov S.A. Lunyaka K.V., Mykhailyk V.D. (2006). Modeliuvannia hidrodynamiky vibrokypliachykh shariv. Visnyk Ternopilskoho derzhavnoho universytetu, 3, 188195.

17. Rusanov S.A., Lunyaka K.V., Smahin P.V. (2007). Doslidzhennia protsesu vibrokypinnia dyspersnykh seredovyshch, 1 ,132-141.

18. Rusanov S.A. Lunyaka K.V., Ardashev V.A. (2007). Nekotorye teoreticheskie aspekty protsessa vibrokipeniia. 6, 5, 30, 23-25.

19. Ambartsumian S. A. (1982). Raznomodulnaia teoryia upruhosty. M.: Nauka, 317.

20.Sadovskaia O.V. Sadovskyi V.M. (2008). Matematycheskoe modelirovanie $\mathrm{v}$ zadachakh mekhaniki sypuchikh sred. Monohrafiia. M.: Fyzmatlyt, 368. 
21. Systema avtomatyzovanoho modeliuvannia hidrodynamiky vibrokypliachykh shariv "Vybrosloi 1.0". Svidotstvo pro reiestratsiiu avtorskoho prava na tvir №25051. / S.A. Rusanov: Zaiavl. 14.04.2008; Opubl. 24.07.2008.

22. Kroll W. (1955). Fliesserscheinungen auf Haufwerken in schwingenden. Chemic Ingenieur Technik, 1, 142-148. https://doi.org/10.1002/cite.330270110

23. Rusanov S.A. (2008). Modeliuvannia hidrodynamiky vibrokypliachykh shariv $\mathrm{z}$ rozrobkoiu utylizatora tepla sypkykh materialiv: dys. ... kand. tekhn. nauk / S.A. Rusanov. - Kherson, 189.

24. Rusanov S.A. Lunyaka K.V., Kliuiev O.I., Hlukhov H.M. (2009). Vzaiemodiia vibrokypliachoho sharu z nesuchymy poverkhniamy. Vostochno-evropeiskii zhurnal peredovykh tekhnolohii. 5, 5, 41, 9-14. https://doi.org/10.1007/s10891-012-0772-0

Received 23 October 2018 Approved 04 December 2018 Available in Internet 30 December 2018 